\title{
DNA Binding and Cleavage Activity of Three New Copper (II) Complexes of Chiral N-salicyl- $\beta$-amino Alcohol Schiff Bases
}

\author{
Turgay Tunç*1, Nadir Demirel², Mahmut Emir ${ }^{2}$, Aslıhan Günel $^{2}$, Mehmet Çolak $^{3}$, Nurcan Karacan ${ }^{4}$ \\ ${ }^{1}$ Department of Chemistry Engineering and Process, Faculty of Engineering, University of Ahi Evran, \\ Kursehir.; 40100, Turkey \\ ${ }^{2}$ Department of Chemistry, Faculty of Science \& Art, University of Ahi Evran, Krrsehir.; 40100; Turkey \\ ${ }^{3}$ Department of Chemistry.; Faculty of Science.; University of Dicle.; Diyarbakır.; 21280.; Turkey \\ ${ }^{4}$ Department of Chemistry.; Faculty of Science.; University of Gazi.; Ankara.;06500.; Turkey
}

* Corresponding author: Tel.: +90 038622 00; fax: +90 038628038 01, e-mail: ttunc@ahievran.edu.tr

Received December $6^{\text {th }}, 2017$; Accepted May 16 ${ }^{\text {th }}, 2018$.

DOI: http://dx.doi.org/10.29356/jmcs.v62i3.424

\begin{abstract}
Three new copper(II) complexes (1-3) with general formula $\left[\mathrm{Cu}(\mathrm{HL}) \mathrm{CH}_{3} \mathrm{COO}\right]$ of N-salicyl- $\beta$ amino alcohol Schiff bases containing, $(S)-(+)$-phenyl glycinol, $(1 S, 2 R)$-2-amino-1, 2-diphenylethanol and 1, 1, 3-triphenyl- $(R)-(+)-2$-amino propanol, were synthesized. Their structures were characterized by FTIR, LCMS, magnetic moment, molar conductance and elemental analysis data. DFT calculations proposed distorted square planar geometries for the complexes. The calculated IR spectra are in good agreement with the experimental IR spectra, confirming the proposed structures. Their interactions with calf thymus DNA were investigated and their binding constants $\mathrm{K}_{\mathrm{b}}$ were found. Gel electrophoresis reveals that all complexes display significant nuclease activity against supercoiled pentry/d-topo plasmid DNA.
\end{abstract}

Keywords: Copper (II) complexes; DFT calculations; DNA binding; DNA cleavage; Schiff base complexes.

Resumen. Tres nuevos complejos de cobre (II) (1-3) con la fórmula general [Cu (HL) $\mathrm{CH}_{3} \mathrm{COO}$ ] de N-salicil$\beta$-amino alcohol Schiff bases que contienen, $(S)$ - $(+)$ - fenilglicinol, $(1 \mathrm{~S}, 2 R)$. Se sintetizaron -2-amino-1, 2difeniletanol y 1, 1, 3-trifenil- $(R)$ - $(+)$ - 2-amino propanol. Sus estructuras se caracterizaron por FTIR, LCMS, momento magnético, conductancia molar y datos de análisis elemental. Los cálculos de DFT propusieron geometrías planas cuadradas distorsionadas para los complejos. Los espectros de IR calculados están en buena concordancia con los espectros de IR experimentales, confirmando las estructuras propuestas. Se investigaron sus interacciones con el ADN del timo de ternera y se encontraron sus constantes de unión $\mathrm{Kb}$. La electroforesis en gel revela que todos los complejos muestran una actividad nucleasa significativa contra el ADN plasmídico pentry / d-topo superenrollado.

Palabras clave: Complejos de Cobre (II); Cálculos DFT; unión al ADN; ruptura de DNA; Complejos de base de Schiff.

\section{Introduction}

Chiral complexes have important applications in many fields such as enantioselective catalysts, material sciences, metallo-supramolecular chemistry and bio-inorganic modeling studies [1]. They catalyze various asymmetric organic transformations giving high enantioselectivity $[2,3]$. In recent years, Schiff-bases derived from chiral amino alcohols and their transition metal complexes have been reported to catalyze the enantioselective Henry reaction [4-6]. 
$\mathrm{Cu}(\mathrm{II})$ are well known to be a redox-active metal whose complexes can generate reactive oxygen species (ROS) which trigger DNA degradation and apoptosis of cancer [7-9]. Schiff bases copper(II) complexes have been extensively studied as encouraging alternatives to cisplatin and anticancer drugs [1012]. Several copper complexes have been started pre-clinical research as antitumor drug candidates, which demonstrated relatively lower side effects compared with some platinum drugs [13].

The synthesis and design of chiral metal complexes have attracted a considerable amount of attention because they can bind to DNA, and changes their photophysical properties [1]. In previous work, DNA binding and cleavage studies of chiral copper complexes have been broadly investigated [14-19]; however, study on Schiff bases copper complexes with chiral amino-alcohols have rarely been reported [20-23].

In this paper, we synthesized new copper(II) complexes of Schiff bases derived from $(S)-(+)$-phenyl glycinol (1), (1S, 2R)-2-amino-1, 2-diphenylethanol (2) and 1,1,3-triphenyl-(R)-(+)-2-amino propanol (3). Their interactions with CT-DNA were investigated. DNA cleavage activity with supercoiled pentry/d-topo plasmid DNA has also been carried out.

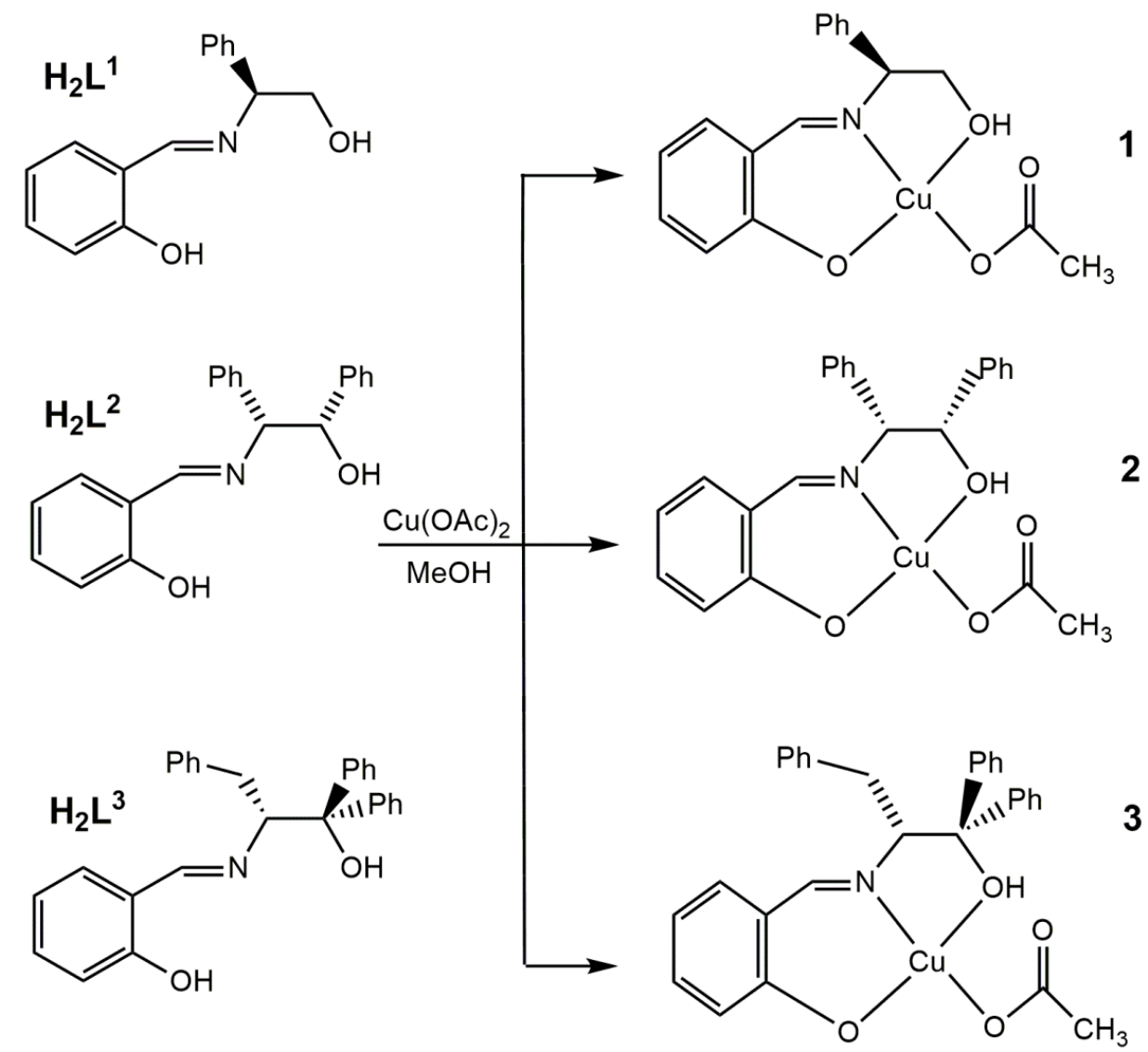

Scheme 1. Synthesis route and proposed structure of the copper (II) complexes.2. Experimental

\section{Materials and Physical Measurements}

All reagents s and solvent were purchased from Sigma Aldrich and used without further purification. Elemental analyses for $\mathrm{C}, \mathrm{H}$ and $\mathrm{N}$ were carried out with a LECO CHNS-932 auto elemental analyzer. The copper analysis was carried out by Varian Atomic Absorption spectrophotometer (AAS) model-AA55B. Mass spectra were recorded with Thermo Scientific TSQ Quantum Access Max LC-MS spectrometers in methanol/acetonitrile mixture. IR spectra were recorded on a Nicolet-6700 ATR-FT-IR spectrophotometer. UV-Vis spectra were recorded on Thermo Scientific Genesys 10S spectrophotometer. The magnetic 
susceptibility was carried out using a Sherwood Scientific instrument at room temperature. The molecular conductivities of the copper(II) complexes were measured with a WTW Cond 330i conductivity meter. All measurements were carried out at room temperature with freshly prepared solutions. Melting points were measured using a Thermo Fisher Scientific Electrothermal 9100 apparatus.

\section{Synthesis of the $\mathrm{Cu}(\mathrm{II})$ complexes}

Chiral amino alcohol Schiff bases $\left(\mathrm{H}_{2} \mathrm{~L}\right)$ are synthesized according to the reported procedure [24]. An ethanol solution of $(25 \mathrm{~mL})$ of $(18 \mathrm{mmol})$ was added to an ethanol solution of o-hydroxybenzaldehyde (15 mmol). The mixture was refluxed for $16 \mathrm{~h}$. After the reaction completed, mixture evaporated to dryness. The pale yellow solid was crystallized from ethyl acetate.

All complexes were synthesized using the following general procedure (Scheme 1). A methanol solution (10 $\mathrm{mL})$ of the chiral Schiff bases $(0.064 \mathrm{mmol})$ was added dropwise to a methanol solution $(10 \mathrm{~mL})$ of copper (II) acetate $(0.064 \mathrm{mmol}, 11.7 \mathrm{mg})$. The mixture was then refluxed for two hours at $60{ }^{\circ} \mathrm{C}$. After the reaction completed, the mixture was allowed to cool and waited for 2 days at room temperature. The green solid was collected by vacuum filtration and washed twice with $3-5 \mathrm{~mL}$ aliquots of ice-cold methanol and dried under vacuum.

[Cu(HL $\left.\left.{ }^{1}\right) \mathbf{C H}_{3} \mathbf{C O O}\right]$ (1). $\mathrm{C}_{17} \mathrm{H}_{17} \mathrm{CuNO}_{4}$ : Anal. Calcd. C, 56.27; H, 4.72; N,3.86, Cu:17.51. Found: C, 56.35; H, 4.62; N, 3.79, Cu: 17.49. LC-MS (m/z): 380.91[Cu( $\left.\left.\mathrm{HL}^{1}\right) \mathrm{CH}_{3} \mathrm{COO}+\mathrm{NH}_{4}^{+}\right], 334.95\left[\mathrm{MH}_{4}{ }^{-}\right.$ $\mathrm{OH}-\mathrm{CH}_{3}{ }^{+}$], $242.05\left(\mathrm{H}_{3} \mathrm{~L}^{+}\right) \Lambda_{\mathrm{m}}{ }^{\mathrm{o}}: 12.11 \mathrm{ohm}^{-1} \mathrm{~cm}^{2} \mathrm{~mol}^{-1}$ in DMF. $\mu_{\text {eff: }}: 1.84$ BM. Yield: $0.031 \mathrm{~g}(88.9 \%)$, m.p: $104-106^{\circ} \mathrm{C}$.

[Cu(HL $\left.\left.{ }^{2}\right) \mathbf{C H}_{3} \mathbf{C O O}\right]$ (2). $\mathrm{C}_{23} \mathrm{H}_{21} \mathrm{CuNO}_{4}$ : Anal. Calc.: C, 62.93; H, 4.82; N, 3.19. Cu: 14.48, Found: C, 63.30; H, 5.17; N, 3.16, Cu:13.89. LC-MS (m/z): 456.97[Cu( $\left.\left.\mathrm{HL}^{2}\right) \mathrm{CH}_{3} \mathrm{COO}+\mathrm{NH}_{4}{ }^{+}\right], 424.96\left[\mathrm{MH}-\mathrm{CH}_{3}{ }^{+}\right]$, $410.99\left[\mathrm{MH}_{4}-\mathrm{OH}-\mathrm{CH}_{3}\right], 396.93\left[\mathrm{MH}-\mathrm{CO} . \mathrm{CH}_{3}\right], 318.06\left(\mathrm{H}_{3} \mathrm{~L}^{+}\right) . \Lambda_{\mathrm{m}}{ }^{\mathrm{o}}: 11.25 \mathrm{ohm}^{-1} \mathrm{~cm}^{2} \mathrm{~mol}^{-1}$ in DMF. $\mu_{\text {eff: }} 1.85$ BM. Yield: $0.036 \mathrm{~g}(82.9 \%)$, mp: $122-124^{\circ} \mathrm{C}$.

[CuHL ${ }^{3} \mathbf{C H}_{3} \mathbf{C O O}$ (3). $\mathrm{C}_{30} \mathrm{H}_{27} \mathrm{CuNO}_{4}$ : Anal. Calc C, 68.10; H, 5.14; N, 2.65. Cu: 12.01, Found: C, 68.41; H, 6.52; N, 2.39, Cu: 11.30. LC-MS $\left(\mathrm{m} / \mathrm{z}^{+}\right): 547.01\left[\mathrm{CuHL}^{3} \mathrm{CH}_{3} \mathrm{COO}+\mathrm{NH}_{4}\right]^{+}, 515.02\left[\mathrm{MH}-\mathrm{CH}_{3}\right]^{+}$, $501.04\left[\mathrm{MH}_{4}-\mathrm{OH}-\mathrm{CH}_{3}\right]^{+}, 408.06\left[\mathrm{M}-\mathrm{CH}_{3} \mathrm{CO}-\mathrm{Ph}\right]^{+} . \Lambda_{\mathrm{m}}{ }^{\mathrm{o}}: 14.45 \mathrm{ohm}^{-1} \mathrm{~cm}^{2} \mathrm{~mol}^{-1}$ in DMF. $\mu_{\text {eff: }} 1.83$ BM. Yield: $0.042 \mathrm{~g}(79.4 \%), \mathrm{mp}: 123-125^{\circ} \mathrm{C}$.

\section{Computational method}

Theoretical calculations were performed with Gaussian 03W(B.04) software [25] and visualized using GVW (Rev 2.1) [26]. Since we were not able to obtain the single crystals of the complexes, the experimental data of starting geometries were taken from the earlier published studies [27, 28]. Geometry optimization of complexes were carried out using several DFT methods such as CAM-B3LYP/6-31G(d,p), CAM-B3LYP/6-311G(d,p), B3LYP/6-31G(d,p), B3LYP/6-311G(d,p) and B3LYP/6-311G+(d,p) for all atoms. Harmonic vibrational frequencies and IR intensities of the normal modes were calculated at the same level, and no imaginary frequencies were found, confirming that the structures correspond to minimum energy. The calculated frequencies were scaled by $0.97-0.98$. Vibrational frequency assignments were made with GVW software to display the vibrations.

\section{DNA Binding Studies}

Interaction of the complexes with CT-DNA was conducted in Tris buffer $(5 \mathrm{mM}, \mathrm{pH} 7.1)$. A solution of the CT-DNA in the buffer solution give a ratio of UV-Vis absorbance at 260 and $280 \mathrm{~nm}$ of about 1.9:1 indicating that the DNA was free from proteins [29]. DNA concentration was determined by the molar extinction coefficient $\left(6600 \mathrm{M}^{-1} \mathrm{~cm}^{-1}\right)$ at $260 \mathrm{~nm}$ [30]. Absorption spectral titration experiments were performed by maintaining a constant concentration of the complex and varying the CT-DNA concentration. While measuring the absorbance, recorded after consecutive additions of CT-DNA, CT-DNA was added to both the compound solution and the reference solution to eliminate the absorbance of the CT-DNA itself. The intrinsic binding constant $\mathrm{K}_{\mathrm{b}}$ of the complexes to CT-DNA was determined from following equation [31]. 


$$
[D N A] /\left(\varepsilon_{a}-\varepsilon_{f}\right)=[D N A] /\left(\varepsilon_{b}-\varepsilon_{f}\right)+1 / K_{b}\left(\varepsilon_{b}-\varepsilon_{f}\right)
$$

where [DNA] represents the concentration of DNA in base pairs; $\varepsilon_{\mathrm{a}}, \varepsilon_{\mathrm{f}}$, and $\varepsilon_{\mathrm{b}}$ correspond to the apparent extinction coefficient (Aobs/[M]), the extinction coefficient of the free metal and the extinction coefficient of the complex bound to DNA, respectively. The plot of $[D N A] /(\varepsilon a-\varepsilon f)$ vs [DNA] gave a straight line with a slope of $1 /(\varepsilon b-\varepsilon f)$ and an intercept of $1 / \mathrm{Kb}(\varepsilon b-\varepsilon f)$. Kb was determined from the ratio of the slope to intercept.

\section{DNA Cleavage Experiment}

Native super coiled pentry/d-topo plasmid DNA was purified using Perfect Prep Endo Free Plasmid Maxi Kit according to manufacturer instructions. Solution of plasmid DNA gave a ratio of UV absorbance at 260 and $280 \mathrm{~nm}, \mathrm{~A} 260 / \mathrm{A} 280$ of ca.180 and 1.90, indicating that the DNA was free from protein contamination. A stock solution of complexes were prepared at a concentration of $500 \mu \mathrm{M}$. Plasmid DNA (22 $\mu \mathrm{L})$ in a final volume of $50 \mu \mathrm{L}$ were treated with varying concentration of complexes $(20-150 \mu \mathrm{M})$ and incubated in the dark for $12 \mathrm{~h}$ at $37^{\circ} \mathrm{C} .20 \mu \mathrm{L}$ of each sample and $10 \mu \mathrm{L}$ of the loading dye were loaded onto $1 \%$ agarose gel in $1 \mathrm{X}$ TAE buffer (Tris-Acetate-EDTA. Agarose gel electrophoresis was performed at $75 \mathrm{~V}$ for $90 \mathrm{~min}$. Later gel was stained with ethidium bromide solution $(10 \mathrm{mg} / \mathrm{mL})$ and the bands were observed under UV gel documentation system (Gene Tools image analysis software from Syngene). This software provides comparison of tracks in agarose gel according to their band numbers and/or band densities. (This evaluation was performed by comparing the either volume of bands in the lanes or calculating the volume of newly formed bands with control plasmid DNA).

\section{Results and discussion}

\section{Synthesis and general characterization}

The copper(II) complexes (1-3) were synthesized by the reaction of cupric acetate with chiral Nsalicyl- $\beta$-amino alcohol Schiff bases prepared by condensation reaction of $o$-hydroxybenzaldehyde with $S$ )$(+)$-phenyl glycinol $\left(\mathrm{H}_{2} \mathrm{~L}^{1}\right),(1 S, 2 R)$-2-amino-1, 2-diphenylethanol $\left(\mathrm{H}_{2} \mathrm{~L}^{2}\right)$ and 1,1,3-triphenyl- $(R)-(+)$-2-amino propanol $\left(\mathrm{H}_{2} \mathrm{~L}^{3}\right)$ in an equimolar ratio. Their crystals were unsuitable for single-crystal $\mathrm{X}$-ray structural determination. Their elemental analysis data indicate that the metal to ligand ratio is $1: 1$ in all the complexes. Their molar conductivities $\left(\Lambda_{\mathrm{m}}\right)$ in DMF solution $\left(1 \times 10^{-3} \mathrm{M}\right)$ at $25^{\circ} \mathrm{C}$ were in the range of $12-16 \mathrm{Ohm}^{-}$ ${ }^{1} \mathrm{~cm}^{2} \mathrm{~mole}^{-1}$, indicating that all complexes are non-electrolytes. LC-MS spectra of the complexes were depicted in Fig.1. The positive ion electrospray mass spectra have exhibited $\left[\mathrm{M}+\mathrm{NH}_{4}\right]^{+}$molecular ion peaks at 380.91 for $\mathbf{1}, 456.97$ for $\mathbf{2}$ and 547.01 for $\mathbf{3}$. Adduct ion as $\left[\mathrm{M}+\mathrm{NH}_{4}\right]^{+}$is reported in literature to be frequently observed in ESI analysis [32]. Demetallation fragment $\left(\mathrm{H}_{3} \mathrm{~L}^{+}\right)$gave a base peak at 242.05 for $\mathbf{1}$ and 318.06 for 2. Other fragments correspond to the homolytic cleavage of $\mathrm{OH}$ and/or $\mathrm{CH}_{3}$ groups. Based on these results, the structures of the complexes were suggested to be as shown in Scheme 1. Similarly, copper (II)- Schiff base complexes with 1:1 molar ratio, having $\mathrm{Cu}(\mathrm{L})(\mathrm{OAc}) \cdot \mathrm{CH}_{3} . \mathrm{OH}$ formula, was reported in literature [33]. 

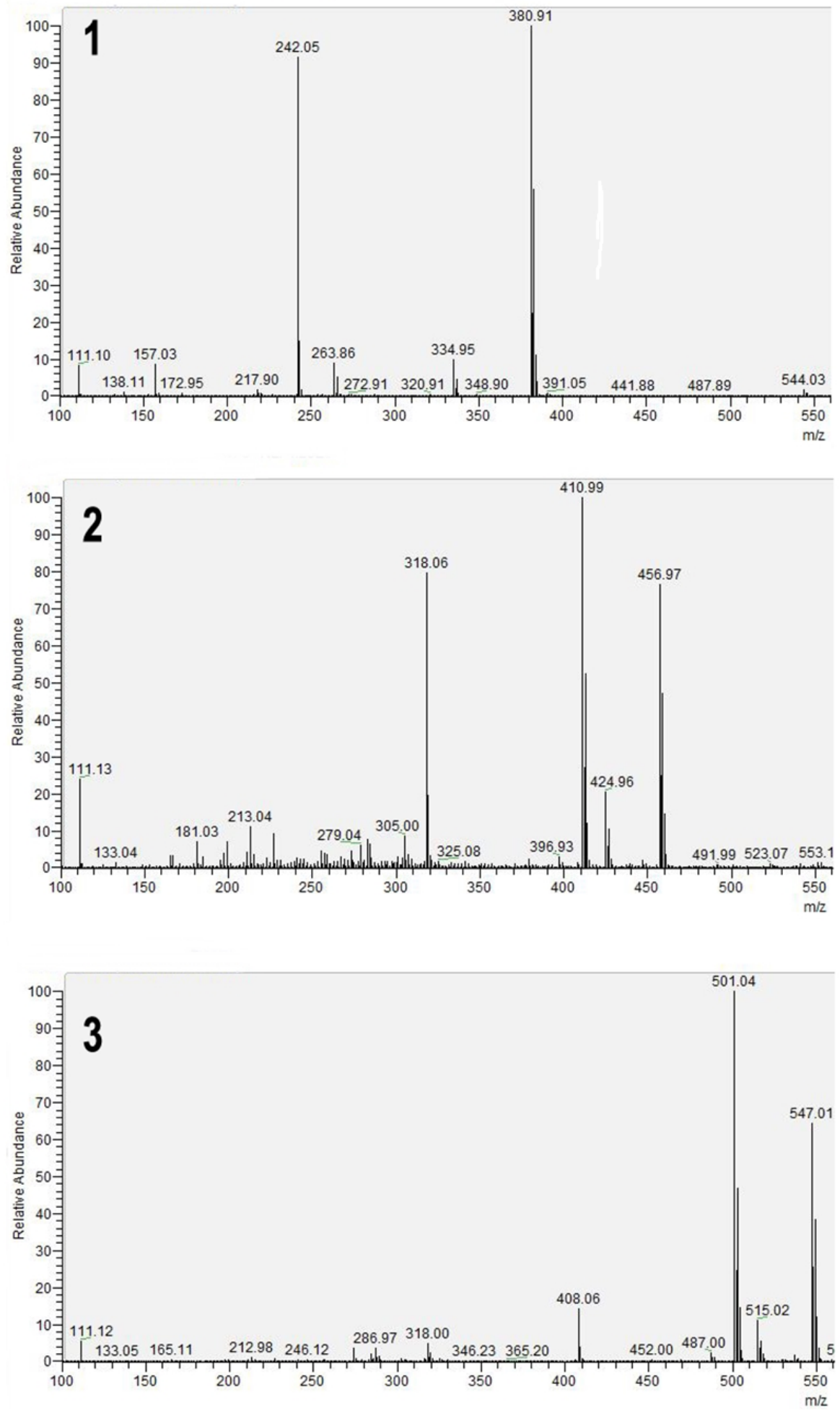

Fig. 1. LC-MS spectra of the copper (II) complexes. 


\section{Geometry optimization of the complexes}

Geometry optimization gives more information about atomic arrangement, without crystal data, and also provides the most stable structure. It is well-known that acetate group behaves as both terminal and bridging, and both monodentate and bidentate ligand [33-36]. We attempt to optimize the monomeric $\left[\mathrm{Cu}(\mathrm{HL})\left(\eta^{1}\right.\right.$-acetato $\left.)\right]$ and $\left[\mathrm{Cu}(\mathrm{HL})\left(\eta^{2}\right.\right.$-acetato $\left.)\right]$ complexes. Geometry optimization results clearly indicated that the acetate group coordinated in a monodentate mode to make hydrogen bonding with alcohol group. The ground state geometry optimized at DFT/B3LYP/6-311G+(d,p) level in gas phase of the complexes (1-3) are shown in Fig. 2. Except for substituent differences, the overall structures of the (1-3) are very similar. The geometry around the copper is a distorted square-planar geometry with tridentate ligand (ONO) and monodentate acetate ligand. In each structure, monoanionic ligand coordinates to copper atom through the alcoholic-O, the imine- $\mathrm{N}$ and the phenolic-O atoms forming six-membered and five-membered chelate rings. One $\mathrm{O}$ atom of the acetate ligand completes a distorted $\mathrm{N}_{2} \mathrm{O}_{2}$ square-plane around the metal center. Intramolecular hydrogen bond in the complexes $\left(\mathrm{O}-\mathrm{H} \ldots . . \mathrm{O}_{\mathrm{ac}}\right)$ is formed between alcoholic- $\mathrm{H}$ and second oxygen atom of the acetateligand and stabilize the molecular conformation. The trans- $\mathrm{N}-\mathrm{Cu}-\mathrm{O}$ (acetato) and trans-O$\mathrm{Cu}-\mathrm{O}$ bond angles deviate significantly from the true square planar $180^{\circ}$ angles and are calculated to be $163.4( \pm 0.3)^{\circ}$ and $168.5( \pm 0.3)^{\circ}$, respectively in all complexes, and are similar to those found in related structures [23, 33]. Calculated $\mathrm{Cu}-\mathrm{O}$ (acetate) bond lengths are 1.93( \pm 0.01$) \AA$, which is comparable with the values reported before $[33,37]$; whereas, the calculated distances between the copper atom and the other Oatom of the acetate ligand are $2.43( \pm 0.01) \AA$ in all complexes, indicating that there is no covalent bond between them, and acetate group behaves as monodentate ligand.

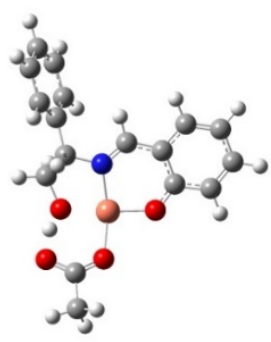

2

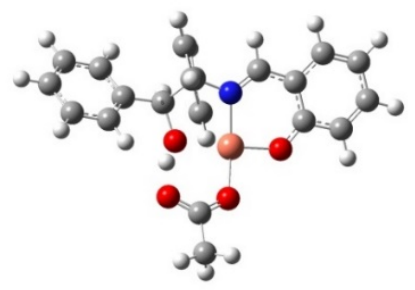

3

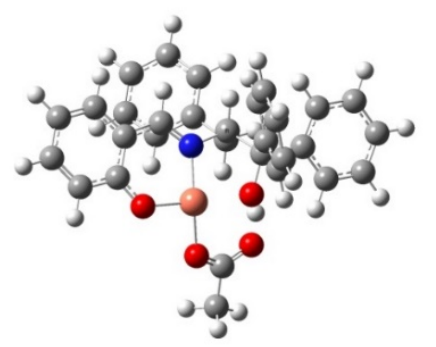

Fig. 2. The optimized molecular geometries of the copper (II) complexes, calculated by DFT/B3LYP/6$311 \mathrm{G}+(\mathrm{d}, \mathrm{p})$ method in gas phase. 


\section{IR spectra of the complexes}

Observed FTIR spectra of the complexes were illustrated in Figs 3-5, which are very similar to each other. Their harmonic vibrational frequencies were calculated with three different basis set, CAM-B3LYP/6$31 \mathrm{G}(\mathrm{d}, \mathrm{p})$, B3LYP/6-311G(d,p) and B3LYP/6-311+G(d,p) in gas phase. For comparison, calculate and experimental spectra were given for 2 in Fig.6. As seen in Fig 6, theoretical vibrational frequencies computed with B3LYP/6-311+G(d,p) showed good agreement with experimental results. Similarity between the spectral patterns theoretical and experimental IR spectra were confirmed the proposed structures. The calculatedobserved agreement is satisfactory. Little deviations can be attributed to two factors: crystal packing effects and the negligence of anharmonicity. The average error in frequencies calculated by B3LYP method is reported to be of the order of 40-50 $\mathrm{cm}^{-1}$ [38] Because the DFT/B3LYP methods overcalculate normal mode frequencies due to a combination of basis set deficiencies and electron correlation effects. Therefore, calculated frequencies were corrected with scaling factors of 0.98-0.96 to obtain better agreement with experimental and calculated frequencies. The observed frequencies have been assigned with the calculated peak intensities and scaled peak frequencies. Experimental and calculated frequencies of selected vibrational modes for the complexes were given in Table 1.

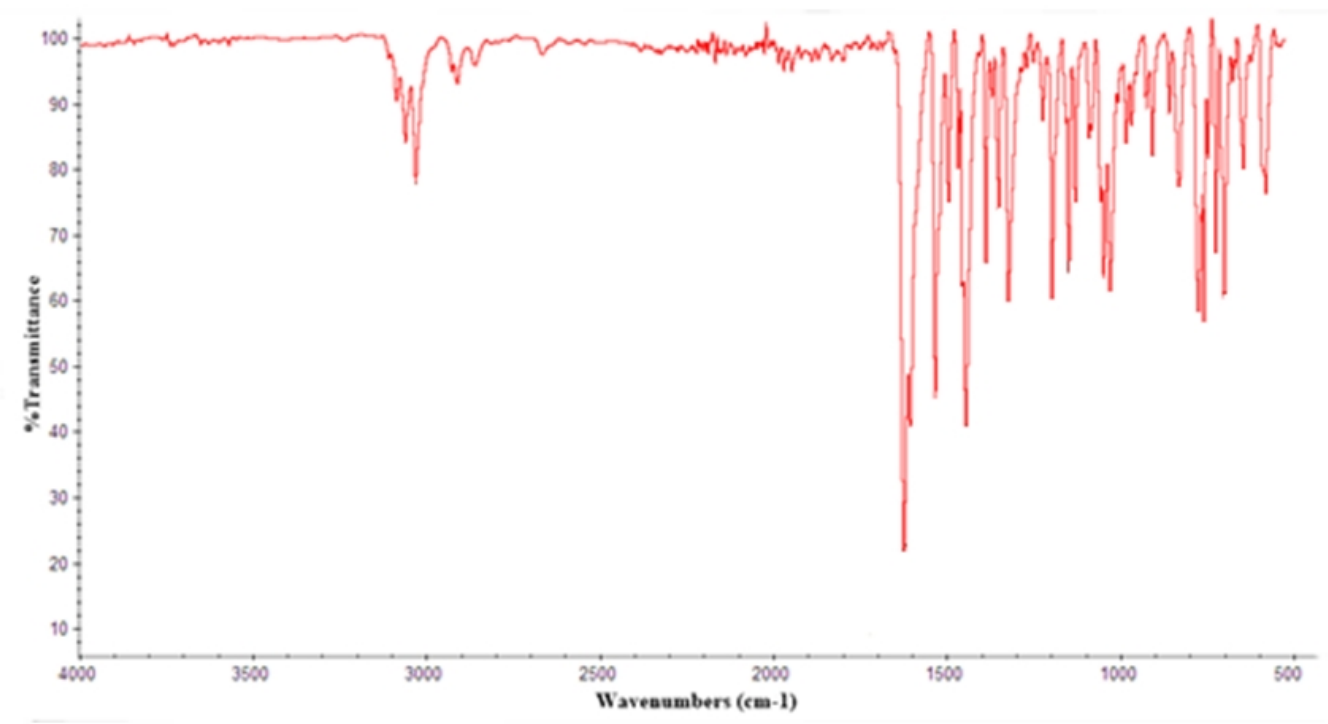

Fig. 3. IR spectrum of the $\mathbf{1}$. 


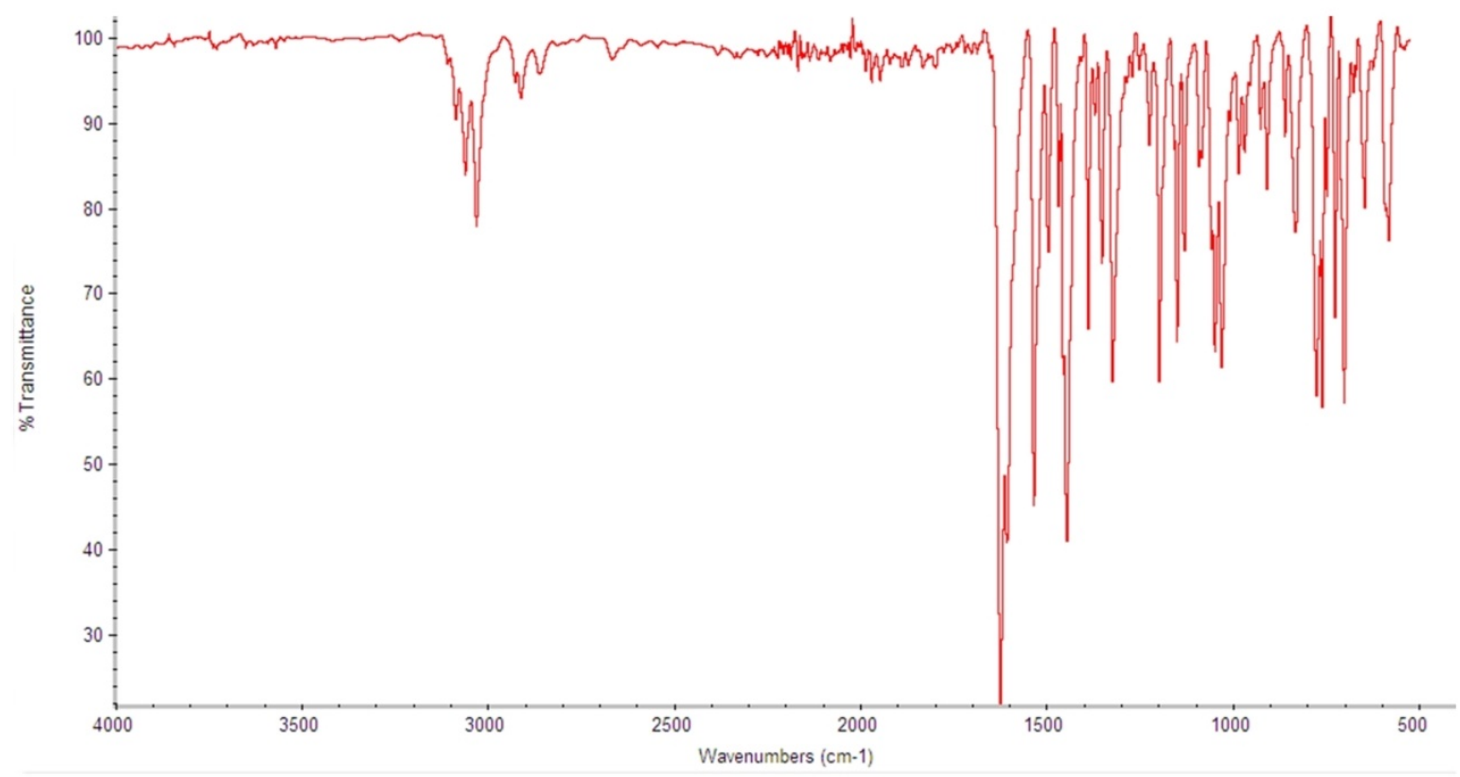

Fig. 4. IR spectrum of the 2 .

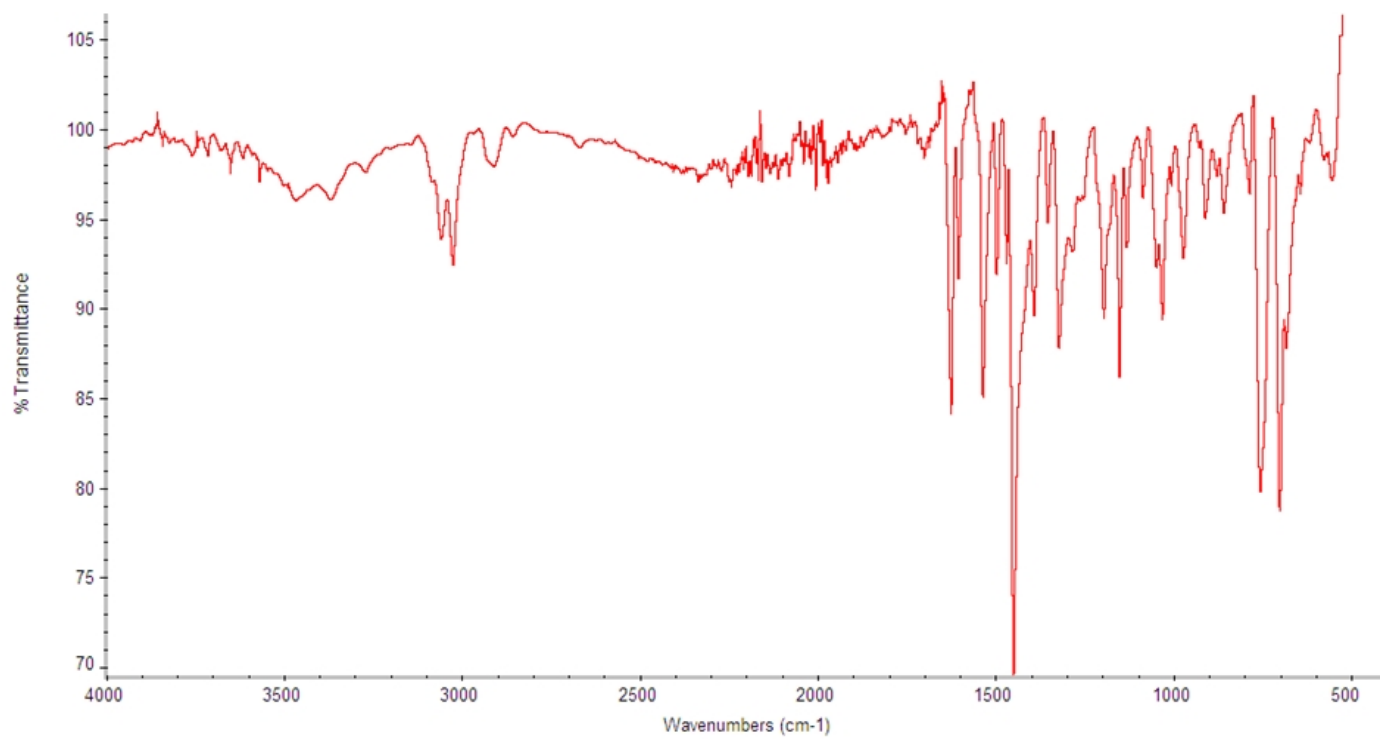

Fig. 5. IR spectrum of the 3 . 
Table 1. Experimental and calculated (no scale) wavenumbers of selected vibrational modes of the complexes (1-3).

\begin{tabular}{|c|c|c|c|c|c|c|}
\hline \multicolumn{2}{|c|}{1} & \multicolumn{2}{|c|}{2} & \multicolumn{2}{|c|}{3} & \\
\hline $\exp$ & calc & $\exp$ & calc & $\exp$ & calc & assignment \\
\hline $3083 w$ & 3182 & $3080 w$ & 3184 & $3085 \mathrm{w}$ & 3186 & $\mathrm{~V}_{\mathrm{aCH}}$ \\
\hline $3054 w$ & 3145 & $3058 w$ & 3145 & $3055 \mathrm{w}$ & 3148 & $\mathrm{~V}_{\mathrm{as}(\mathrm{CH} 3)}$ \\
\hline $3024 w$ & 3094 & $3026 w$ & & $3025 \mathrm{w}$ & - & $\operatorname{vas}_{\mathrm{CH} 2}$ \\
\hline- & - & $2929 w$ & 3038 & $2029 w$ & 3038 & $v_{\mathrm{CH}}$ \\
\hline- & - & $2906 w$ & 3018 & 2906w & 3016 & $v_{\mathrm{CH}}$ \\
\hline- & 2376 & - & 2591 & - & 2598 & $v_{\mathrm{OH}}($ alcoholic $)$ \\
\hline $1623 \mathrm{vs}$ & 1654 & $1621 \mathrm{vs}$ & 1655 & $1620 \mathrm{vs}$ & 1656 & $v_{\mathrm{C}=\mathrm{N}}$ \\
\hline $1600 \mathrm{~s}$ & 1636 & $1602 \mathrm{~s}$ & 1636 & $1600 \mathrm{~s}$ & 1636 & $v \mathrm{C}=\mathrm{C}($ ar $)$ \\
\hline $1531 \mathrm{~s}$ & 1598 & $1529 \mathrm{~s}$ & 1601 & $1531 \mathrm{~s}$ & 1604 & $\mathrm{v}_{\mathrm{as}} \mathrm{COO}+\delta \mathrm{OH}$ \\
\hline $1490 \mathrm{~m}$ & 1556 & $1491 \mathrm{~m}$ & 1557 & $1493 \mathrm{~m}$ & 1556 & $v \mathrm{C}=\mathrm{C}(\mathrm{ar})$ \\
\hline $1461 \mathrm{~m}$ & 1478 & $1462 \mathrm{~m}$ & 1480 & $1465 \mathrm{~m}$ & 1482 & $\delta_{\mathrm{CH} 3}(\mathrm{ac})$ \\
\hline $1444 \mathrm{~s}$ & 1471 & $1440 \mathrm{~s}$ & 1467 & $1444 \mathrm{vs}$ & 1469 & $\delta_{\mathrm{CH}(\mathrm{ar})}$ \\
\hline $1386 \mathrm{~m}$ & 1435 & $1385 \mathrm{~m}$ & 1431 & $1387 \mathrm{~m}$ & 1433 & $v_{\mathrm{s}} \mathrm{COO}$ \\
\hline 1347 & 1390 & $1348 \mathrm{~m}$ & 1388 & $1349 \mathrm{~m}$ & 1392 & $\mathrm{vCO}$ \\
\hline $1319 \mathrm{~m}$ & 1374 & $1318 \mathrm{~s}$ & 1372 & $1317 \mathrm{~m}$ & 1371 & $\delta \mathrm{CH}_{3}$ (umbrella) \\
\hline $1215 \mathrm{~m}$ & 1254 & $1217 \mathrm{~m}$ & 1249 & $1213 \mathrm{~m}$ & 1248 & $\delta_{\mathrm{OH}}$ \\
\hline $1190 \mathrm{~m}$ & 1214 & $1193 \mathrm{~s}$ & 1208 & $1191 \mathrm{~m}$ & 1210 & $\delta_{\mathrm{CH}(\mathrm{ar})}+\delta_{\mathrm{OH}}$ \\
\hline $1146 \mathrm{~m}$ & 1174 & $1145 \mathrm{~m}$ & 1176 & $1146 \mathrm{~m}$ & 1175 & $\delta_{\mathrm{CH}(\mathrm{ar})}$ \\
\hline $1125 \mathrm{~m}$ & 1150 & $1126 \mathrm{~m}$ & 1153 & $1128 \mathrm{w}$ & 1155 & $\delta_{\mathrm{CH}(\mathrm{ar})}$ \\
\hline $1403 w$ & 1110 & $1043 \mathrm{~s}$ & 1113 & $1043 w$ & 1114 & $v_{\mathrm{C}-\mathrm{N}}+\delta_{\mathrm{CH}(\mathrm{ar})}$ \\
\hline 1026 & 1046 & $1025 \mathrm{~s}$ & 1048 & $1027 \mathrm{~m}$ & 1047 & $\gamma_{\mathrm{OH}}$ \\
\hline $903 w$ & 926 & $904 \mathrm{~m}$ & 927 & $903 \mathrm{~m}$ & 928 & Sring \\
\hline $853 w$ & 870 & $854 \mathrm{~m}$ & 868 & $851 \mathrm{~m}$ & 869 & Sring \\
\hline 754 & 766 & $772 \mathrm{~s}$ & 796 & $752 \mathrm{~s}$ & 768 & $\gamma \mathrm{CH}(\mathrm{ar})$ \\
\hline 698vs & 718 & 696vs & 708 & 696vs & 710 & $\gamma \mathrm{CH}(\mathrm{ar})$ \\
\hline $645 \mathrm{~m}$ & 678 & $643 \mathrm{~m}$ & 679 & $646 \mathrm{~m}$ & 680 & $\gamma \mathrm{COO}$ \\
\hline 580w & 619 & $577 \mathrm{~m}$ & 592 & $584 w$ & 620 & $\gamma \mathrm{COO}+\gamma$ ring \\
\hline
\end{tabular}

Aromatic C-H stretching vibrations were calculated in the range $3200-3000 \mathrm{~cm}^{-1}$ and assigned in the range $3100-3000 \mathrm{~cm}^{-1}$. The characteristic imine $(-\mathrm{HC}=\mathrm{N}-)$ stretching vibration was computed around 1655 $\mathrm{cm}^{-1}$ and observed as a strong band around at $1623-1620 \mathrm{~cm}^{-1}$ in the complexes. Besides, a medium band near $1460 \mathrm{~cm}^{-1}$ was also assigned to the $\mathrm{CH}_{3}$ asymmetric deformation vibrations of the acetate group [39]. In all three complexes, phenolic $\mathrm{C}-\mathrm{O}$ vibrations shifted to higher wavenumber due to coordination were observed as a medium to high-intensity band around $1348 \mathrm{~cm}^{-1}$.

The theoretical asymmetric stretching $v_{\mathrm{as}}\left(\mathrm{COO}^{-}\right)$and symmetric stretching $v_{\mathrm{s}}(\mathrm{COO})$ frequencies of the acetate ligands in the complexes were computed around 1600 and $1530 \mathrm{~cm}^{-1}$ respectively; in their experimental IR spectra, these vibrations were observed as strong intensity bands around 1530 and $1385 \mathrm{~cm}^{-1}$, respectively. The difference between asymmetric and symmetric stretching vibrations $(\Delta)$ were found to be $145 \mathrm{~cm}^{-1}$. It is claimed that $\Delta$ values gives information about bonding mode of the carboxylate group. Generally, the monodentate acetate ligands have $\Delta>200 \mathrm{~cm}^{-1}$. However, some complexes possesing crystal structures, with unidentate acetate ligands such as $\mathrm{Zn}(\mathrm{ac})_{2}\left(\mathrm{SC}\left(\mathrm{NH}_{2}\right)_{2}\right)_{2}\left(\Delta: 152 \mathrm{~cm}^{-1}\right), \mathrm{Ni}(\mathrm{ac})_{2}\left(\mathrm{H}_{2} \mathrm{O}\right)_{4}(\Delta: 125$ $\left.\mathrm{cm}^{-1}\right)$ and $\mathrm{Ni}\left(\mathrm{ac}_{2}\left(\mathrm{H}_{2} \mathrm{O}\right)_{2}(\mathrm{py})_{2}\left(138 \mathrm{~cm}^{-1}\right)\right.$ were reported $\Delta$ values less than $200 \mathrm{~cm}^{-1}$ [39x]. In this case, the acetate oxygen not coordinated to the metal is hydrogen bonded to other ligands (thiourea or water), giving rise to a "pseudo-bridging" arrangement [40, 41]. On the other hand, $\left[\mathrm{Cu}(\mathrm{ac}) \mathrm{NH}\left(\left(\mathrm{CH}_{2}\right)_{3} \mathrm{NH}_{2}\right)_{2}\right] \mathrm{ClO}_{4}(\Delta: 150$ $\left.\mathrm{cm}^{-1}\right),\left[\mathrm{Cu}(\mathrm{ac})_{2}\left(\mathrm{H}_{2} \mathrm{O}\right)\right]_{2}\left(\Delta: 175\right.$ or $\left.200 \mathrm{~cm}^{-1}\right)$ with bridging acetate ligand, and $\mathrm{Cu}(\mathrm{ac})(\mathrm{PPh} 3) 2(\Delta: 131$ or 160 $\mathrm{cm}^{-1}$ ) with chelating ligand have been reported in literature [40]. Thus, $\Delta$ values more than $200 \mathrm{~cm}^{-1}$ are 
indicative of monodentate acetato groups; however, structures have not been proposed precisely on the basis of $\Delta$ values lower than $200 \mathrm{~cm}^{-1}$.

A broad band at about $3300 \mathrm{~cm}^{-1}$ was assigned to the intra-molecular hydrogen-bonded $\mathrm{OH}$ group [39]. This band is generally displaced to $2840-2960 \mathrm{~cm}-1$ due to internal hydrogen bridge $\mathrm{OH}$...NC [42]. As the hydrogen bond becomes stronger, the bandwidth increases, and this band sometimes cannot be detected [43]. The relatively planar ligands favors intramolecular hydrogen bond formation. For our complexes, the disappearance of this band is expected due to strong intramolecular hydrogen bond between OH group of ligand and free oxygen atom of the acetate group (Fig 2). This expectation is supported by DFTcalculation, and $\mathrm{OH}$ stretching vibration were computed in the region $2376-2598 \mathrm{~cm}^{-1}$. C-H..O or C-H...N intermolecular interactions may also contribute this disappearances. On the other hand, in-plane and out-of plane bending vibrations of $\mathrm{OH}$ groups were assigned as medium bands in the region $1217-1213 \mathrm{~cm}^{-1}$ and strong bands near $1025 \mathrm{~cm}^{-1}$, respectively.

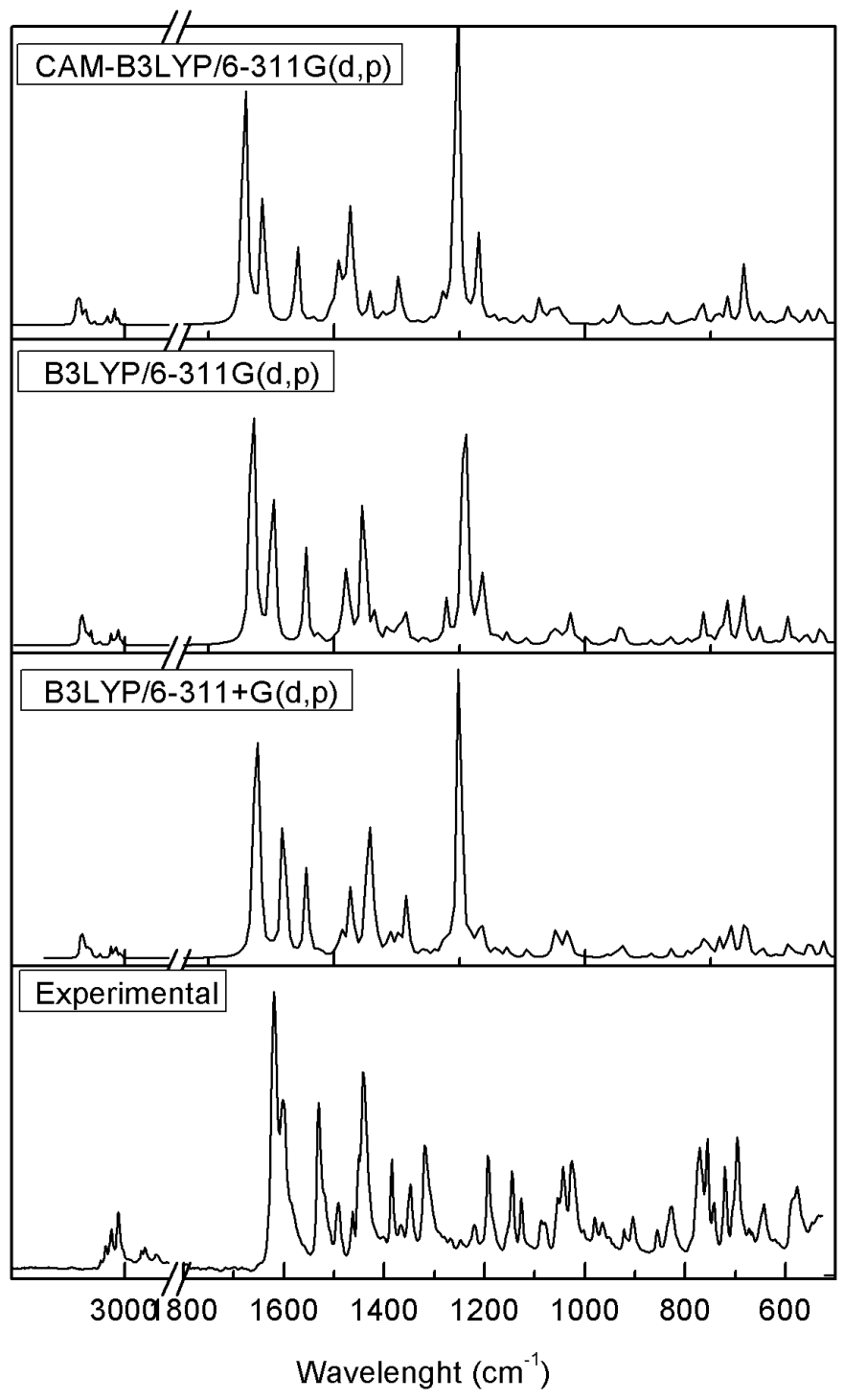

Fig. 6. Calculated and experimental IR spectra of the 2 . 


\section{DNA Binding Studies}

The potential binding ability of the copper (II) complexes (1-3) to CT-DNA was studied using UV absorption spectrometry. The absorption spectra of the titration of the copper(II) complexes $(100 \mu \mathrm{M})$ with CT-DNA from 0 to $250 \mu \mathrm{M}$ are shown in Fig. 7. Absorption band in the range 350-450 nm in the buffer solution correspond to $\pi \rightarrow \pi^{*}$ transition of the aromatic rings of the copper(II) complexes. As seen in Fig.7, the band height at $360 \mathrm{~nm}$ gradually decreases for $\mathbf{1}$ and $\mathbf{2}$, but increases for $\mathbf{3}$. On titration with CT-DNA, complex 1 exhibits slight hypochromic $(6.34 \%)$ and narrow bathochromic $(+9 \mathrm{~nm})$ effects; whereas, complex 2 displays significant hypochromic (14.42\%) and large bathochromic (+12 nm) effects; moreover, complex 3 shows slight hyperchromic $(18.25 \%)$ and narrow hypochromic $(-18 \mathrm{~nm})$ effects.
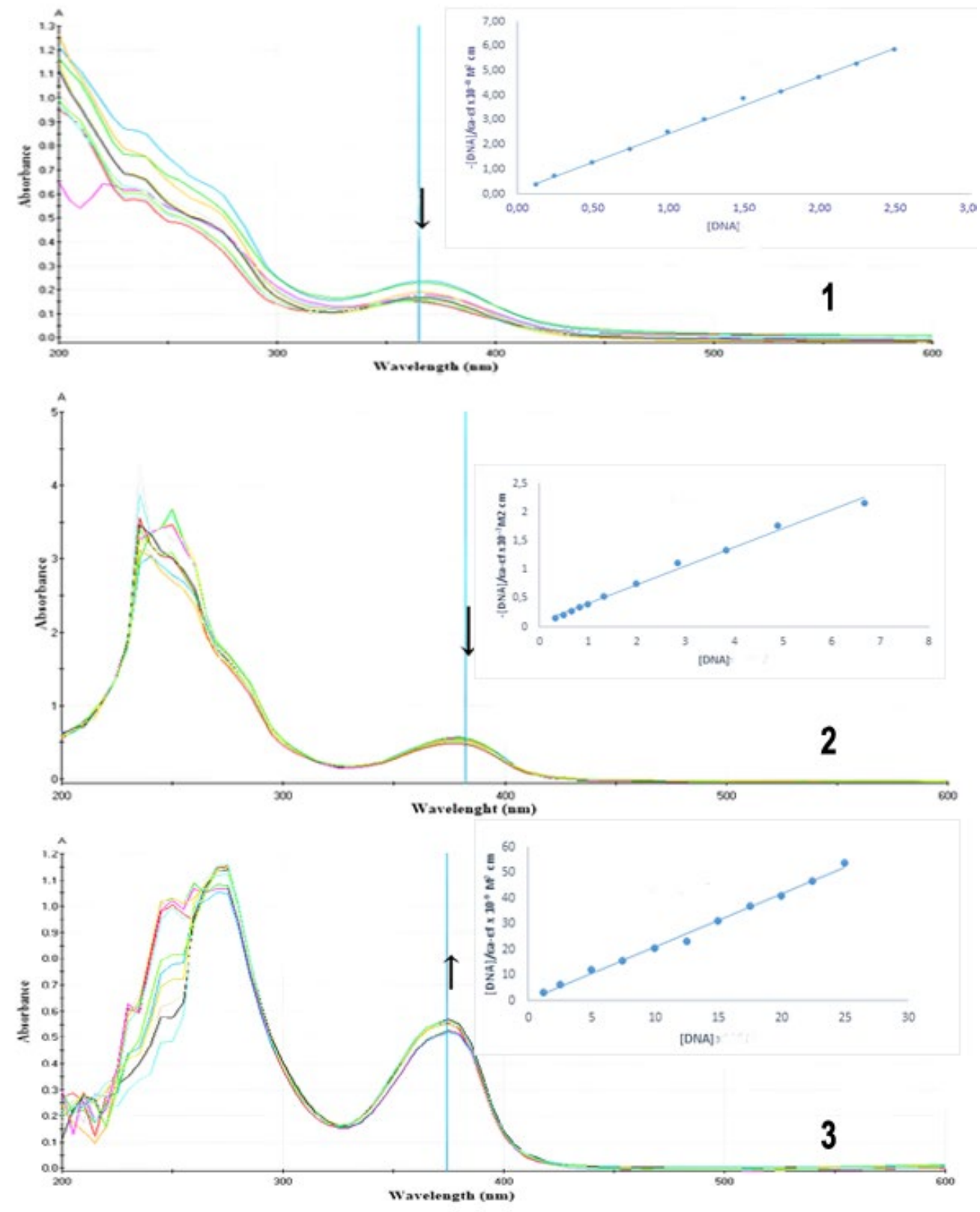

Fig. 7. Electronic absorption spectra of the complexes $(1-3)\left(1 \times 10^{-4} \mathrm{M}\right)$ in the absence and presence of increasing amount of DT-DNA $\left(0-2.5 \times 10^{-4} \mathrm{M}\right)$ in $5 \mathrm{mM}$ Tris buffer at $\mathrm{pH}$ 7.1. Arrows show the changes in absorbance with respect to increase in the DNA concentration. Inset: Plot between [DNA] and [DNA] $/ \varepsilon_{\mathrm{a}}-\varepsilon_{\mathrm{f}}$ 
Hypochromism is caused by parallel stacking of base pairs in a double helix and refer to the presence of intercalation or at last partial intercalation for (2) and (1). Intercalation result from the contraction of DNA in the helix axis due to a strong stacking interaction between an aromatic chromophore and the base pairs of DNA, consequently the energy level of the $\pi-\pi *$ electron transition decreases, which causes a redshift in UV absorption spectra. The extent of the hypochromic is usually proportional to the strength of the interaction. Whereas, hyperchromism is an indication of the reduction in the amount of parallel stacking in double helix resulting from 1,2-intrastrand crosslinking. The extent of the hyperchromism is indicative of the partial or non-intercalative binding modes [43, 45]. On the other hand, cis-platin and analogs were reported to have hyperchromic and bathochromic shifts [46].

In order to compare the DNA-binding strengths of these complexes, the intrinsic binding constant $\mathrm{K}_{\mathrm{b}}$ was determined from the changes in absorbance. The values of $\mathrm{K}_{\mathrm{b}}$ were $4.15 \times 10^{4}(\mathbf{1}), 1.80 \times 10^{5}(\mathbf{2})$ and $2.39 \times 10^{6}(3)$, respectively. Compound (2) contain one more phenyl group than (1), resulting in greater $\mathrm{K}_{\mathrm{b}}$ value and higher hypochromic effect. It was expected result that the more aromatic group increases the noncovalent complex/DNA interaction (intercalation). However, (3) has one more benzyl group than (2), resulting in greater $\mathrm{Kb}$ value but hyperchromic effect. This indicates non-intercalative interaction. It may be assumed that increase in molecular volume prevents the intercalation. In literature, chiral alkanol amine Schiff base copper(II) complexes having $\left[\mathrm{Cu}_{8}\right]^{8+}$ and $\left[\mathrm{Cu}_{4}\right]^{8+}$ units are reported to exhibit hyperchromism [39].

\section{DNA cleavage activity}

The DNA cleavage activity of the complexes for supercoiled pentry/d-topo plasmid DNA was investigated by gel electrophoresis. When supercoiled DNA is subject to electrophoresis, relative migration will be observed for the intact supercoiled form (Form I). If cutting occurs on one strand (nicking), the supercoiled form will relax and generate a slower-moving singly nicked form (Form II). If both strands are cleaved, a double nicked linear form (Form III) that migrates between Form I and Form II will be generated. Plasmid DNA electropherogram traces of the complexes (1-3) with increasing concentration $(5-200 \mu \mathrm{M})$ were given in Fig 8.

As shown in Fig. 6-8, with the increase of the concentrations of the complex 1, the supercoiled DNA decreases and nicked form gradually increases up to $150 \mu \mathrm{M}$ (line 7). However, DNA cleavage activity of the complex 2 is not concentration dependent; maximum conversion of SC DNA into NC DNA was observed at $10 \mu \mathrm{M}$ (line 3) for complex 2 . When the concentration is added to $150 \mu \mathrm{M}$, the linear form (Form III) begins to appear for complex $\mathbf{3}$. The results indicate the following increasing order of cleavage activity: $\mathbf{3}>\mathbf{2}>\mathbf{1}$. This order correlates with binding strength of the complexes to CT-DNA. 

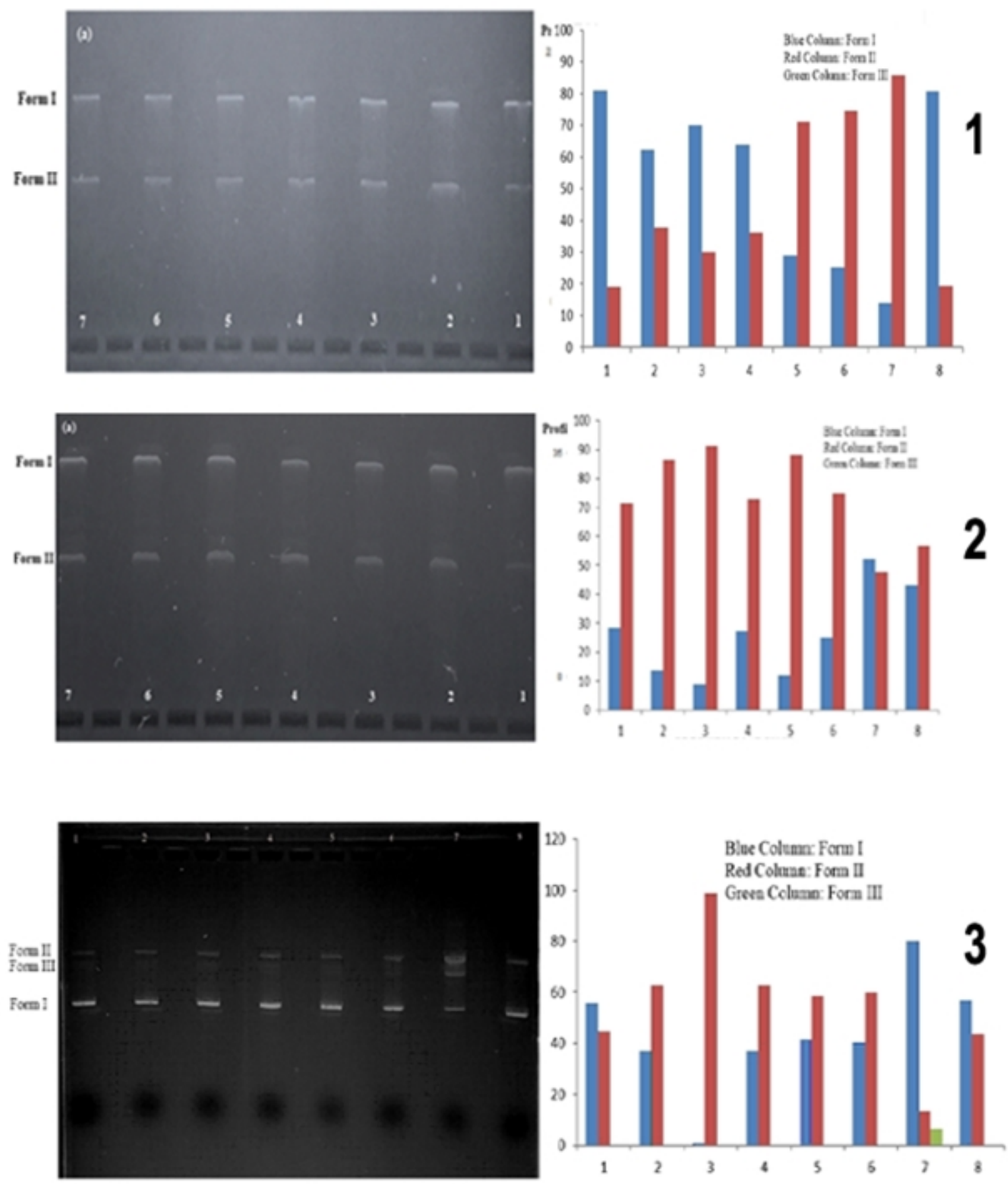

Fig. 8. Plasmid DNA cleavage ( $300 \mathrm{ng})$ in a Tris buffer containing ( $5 \mathrm{mM}$ Tris/ $50 \mathrm{mM} \mathrm{NaCl}, \mathrm{pH} 7.5)$ at $37^{\circ} \mathrm{C}$ with an incubation time for $12 \mathrm{~h}$. Lane1: Control DNA, Lane 2: $5 \mu \mathrm{M}$, Lane 3: $10 \mu \mathrm{M}$, Lane 4: $25 \mu \mathrm{M}$, Lane 5: $50 \mu \mathrm{M}$, Lane 6:100 $\mu \mathrm{M}$, Lane 7: $150 \mu \mathrm{M}$, Lane 8:200 $\mu \mathrm{M}$ complexes(1, 2 and 3) treated plasmid DNA (b) Comparison profiles of the lanes. 


\section{Conclusions}

Three new chiral copper(II) complexes containing chiral Schiff bases derived from chiral ethanolamines, $(S)-(+)$-phenyl glycinol (1), (1S, 2R)-2-amino-1, 2-diphenylethanol (2) and 1,1,3-triphenyl$(R)-(+)$-2-amino propanol (3) have been synthesized and characterized with analytic and spectrophotometric method. DFT calculation proposed that complexes (1-3) have a distorted square-planar geometry with one Schiff base (ONO) and one acetato ligand. In each structure, Schiff bases behave as monoanionic tridentate ligands with the alcoholic-O, the imine- $\mathrm{N}$ and the phenolic-O atoms forming six-membered and fivemembered chelate rings: however, acetate behaves as monodentate ligand with one $\mathrm{O}$ atom. Its other oxygen atom makes intra-molecular hydrogen bond with alcoholic- $\mathrm{H}$ atom of the Schiff base and stabilizes the molecular conformation.

The complex 1 and 2 interact with CT-DNA most likely through the intercalative mode. On increasing the concentration of CT-DNA, hypochromism of $6.34 \%$ and redshift of $9 \mathrm{~nm}$ for $\mathbf{1}$, and hypochromism of $14.42 \%$ and redshift of $12 \mathrm{~nm}$ for 2 are observed. Hypochromism with redshift is pointed out interaction of DNA via ligand intercalation [47]. This kind of findings were observed in another cupperscorpian like ligands [48] However, complex 3 shows hyperchromic effect (18.25\%). The binding constants $\mathrm{K}_{\mathrm{b}}$ of the complexes were observed in the following order $\mathbf{3}>\mathbf{2}>\mathbf{1}$.In other words, the more aromatic rings increase, the higher the binding constants of the complexes. As Magnitudes of binding constants of metal ligand complexes are taken into consideration complex 2 and complex $3 \mathrm{might}$ bind to grooves of DNA double helix since the $\mathrm{Kb}$ of known major groove binder methyl green is order of $10^{6} \mathrm{M}^{-1}$ [49]. All the complexes were found to exhibit nuclease activity. Super coiled pentry/d-topo plasmid DNA cleavage activity studies show that complex $\mathbf{3}$ has best nuclease activity. DNA cleavage activity of the complexes is concentration dependent except complex 2

\section{Acknowledgments}

This study was supported by Ahi Evran University Scientific Research Foundation under grant No FEF.A3.16.015

\section{References}

1. Sharma, S.; Chauhan, M.; Jamsheera, A.; Tabassum, S.; Arjmand, F. Inorg. Chim. Acta. 2017, 458, 827. DOI: 10.1016/j.ica.2016.12.011

2. Chinnaraja, E.; Arunachalam, R.; Choudhary, M.K.; Kureshy, R.I.;d Subramanian, P.S. Appl. Organomet. Chem. 2016, 30, 95-101. DOI: 10.1002/aoc.3404

3. Kumari, P.; Jakhar, A.; Khan, N.H.; Tak, R; Kureshy, R.I.; Abdi, S.H.R.; Bajaj, H.C. Catal. Commun. 2015, 69, 138-142. DOI: 10.1016/j.catcom.2015.06.002

4. Gao, Y-G.; Chen, N.; Wu, H-J.; Li, X-S Russ. J. Org. Chem. 2007, 43,1754-1756. DOI: 10.1134/S1070428007120020.

5. Hsieh, S-H.; Kuo, Y-P; Gau, H-M. Dalton Trans. 2007, 97-106. DOI:10.1039/b613212j

6. Tak, R.; Kumar, M.; Kureshy, R.I.; Choudhary, M. K.; Khan, N.H., Abdi, S.H.R.; Bajaj, H.C. RSC Adv. 2016, 6, 7693-7700. DOI: 10.1039/C5RA23600B

7. Santini, C.; Pellei, M.; Gandin, V.; Porchia, M.; Tisato,F.; Marzano, C. Chem. Rev. 2014, 815-862. DOI: $10.1021 / \mathrm{cr} 400135 \mathrm{x}$.

8. Tisato, F.; Marzano, C.; Porchia, M.; Pellei, M; Santini, C. Med. Res. Rev. 2010, 30,708-749. DOI: 10.1002/med.20174

9. Brissos, R. F.; Torrents, E; Mariana dos Santos Mello, F.; Carvalho Pires, W.; de Paula Silveira-Lacerda, E.; Caballero,A .B.; Caubet, A.; Massera, C.; Roubeau, O.; Teat S.J. and Gamez, P. Metallomics 2014, 
6, 1853-1868. DOI:10.1039/C4MT00152D.

10. Lian, W-J.; Wang, X-T.; Xie, C-Z.; Tian, H.; Song, X-Q.; Pan, H-T.; Qiao, X; Xu, J-Y. Dalton Trans. 2016, 45, 9073-9087. DOI: 10.1039/C6DT00461J

11. Shokohi-pour, Z.; Chiniforoshan, H.; Momtazi-borojeni, A.A.; Notash, B. J. Photochem. Photobiol. B Biol. 2016, 162, 34-44. DOI: 10.1016/j.jphotobiol.2016.06.022

12. Yu, H.; Yang, Y.; Li, Q.; Ma,T.; Xu, J.; Zhu, T.; Xie, J.; Zhu, W.; Cao, Z.; Dong, K.; Huang, J.; Jia, L. Chem Biol Drug Des 2016, 87, 398-408. DOI 10.1111/cbdd.12669

13. Zhang, Z.; Gou, Y.; Wang, J.; Yang, K.; Qi, J.; Zhou, Z.; Liang, S.; Liang, H.; Yang, F. Eur. J. Med. Chem. 2016, 121, 399-409. DOI: 10.1111/cbdd.12669

14. Arjmand, F.; Muddassir, M.; Yousuf, I. J. Photochem. Photobiol. B Biol. 2014,136, 62-71. DOI: 10.1016/j.jphotobiol.2014.04.024

15. da Silveira, V.C.; Luz, J.S.; Oliveira, C.C.; Graziani, I.; Ciriolo, M.R.; da Costa Ferreira, A.M. J. Inorg. Biochem. 2008, 102, 1090-1103. DOI:10.1016/j.jinorgbio.2007.12.033

16. Dezhahang, Z.; Poopari, M.R.; Cheramy, J.; Xu, Y. Inorg. Chem. 2015, 54, 4539-4549. DOI: 10.1021/acs.inorgchem.5b00386

17. Ng, C. H. ; Chan, C.W.; Lai, J.W.; Ooi, I. H.; Chong, K. V.; Maah, M. J.; Seng, H. L. J. Inorg. Biochem. 2016, 160, 1-11. DOI: 10.1016/j.jinorgbio.2016.04.003.

18. Zhang, W.C.; Tang, X.; Lu, X. J. Inorg. Biochem. 2016, 156, 105-112. DOI: 10.1016/j.jinorgbio.2016.01.007

19. Zhou, X-Q; Li, Y.; Zhang, D-Y; Nie, Y; Li, Z-J.; Gu, W.; Liu, X.; Tian, J-L.; Yan, S-P. Eur. J. Med. Chem. 2016, 114, 244-256. DOI: 10.1016/j.ejmech.2016.02.055.

20. Arjmand, F.; Sayeed, F.; Muddassir, M. J. Photochem. Photobiol. B Biol. 2011, 103, 166-179. DOI: 10.1016/j.jphotobiol.2011.03.001

21. Amjad, M.; Sumrra, S.H.; Akram, M.S.; Chohan, Z.H. J. Enzyme Inhib. Med. Chem. 2016, 31, 88-97. DOI: 10.1080/14756366.2016.1220375

22. Yan, H.; Yang, L.; Chang, G-L.;Li, X.; Niu, M-J. Chinese J. Struct. Chem. 2016, 35, 465-471. DOI: 10.14102/j.cnki.0254-5861.2011-0989

23. Niu, M.; Li, Z.; Li, H.; Li, X.; Dou, J.; Wang, S. RSC Adv. 2015, 5, 37085-37095. DOI: 10.1039/C5RA00623F.

24. Çolak, M.; Demirel, N. Tetrahedron: Asymm. 2008, 19, 635-639. DOI: 10.1016/j.tetasy.2008.02.005.

25. Frisch, M.J. Gaussian 03W (Revision B.04). Gaussian. Inc. 2003.

26. Dennington, R. GaussView.W (Rev 2.1). Gaussian. Inc. 2000.

27. Chumakov, Y.M.; Antosyak, B.Y.; Tsapkov, V.I.; Bocelli, G.; Gulya, A.P. Russ. J. Coord. Chem. 2004, 30, 486-490.

28. Dey, M.; Rao, C.P.; Saarenketo P.; Rissanen, K.; Kolehmainen, E. Eur. J. Inorg. Chem. $20022207-$ 2215.

29. Marmur, J. J. Mol. Biol.1961, 3, 208-218. DOI: 10.1016/S0022-2836(61)80047-8

30. Reichmann, M.E.; Rice, S.A.; Thomas, C.A.; Doty, P. J. Am. Chem. Soc., 1954, 76, 3047-3053. DOI: 10.1021/ja01640a067

31. Chen, F-J.; Xu, M.; Xi, P-X.;Liu, H-Y.; Zeng, Z-Z. Spectrochim. Acta - Part A Mol. Biomol. Spectrosc. 2011, 81, 21-27. DOI: 10.1016/j.saa.2011.05.020

32. Keller, B.O.; Sui, J.; Young, A.B.; Whittal, R.M. Anal. Chim. Acta, 2008, 627, 71-81. DOI: 10.1016/j.aca.2008.04.043

33. Kozlyuk, N.; Lopez, T.; Roth, P.; Acquaye, H. Inorg. Chim. Acta. 2015, 428, 176-184. DOI: 10.1016/j.ica.2014.12.034

34. Poyraz, M.; Sar1, M. Acta Crystallogr. Sect. E Crystallogr. Commun. 2017, 73, 209-212. DOI: $10.1107 / \mathrm{S} 2056989017000780$ 
35. Maloth, S.; Pal, S. Polyhedron. 2010, 29, 3257-3261. DOI: 10.1016/j.poly.2010.09.003.

36. Mansour, A.M. Inorg. Chim. Acta. 2013, 408, 186-192. DOI: 10.1016/j.ica.2014.12.034

37. Vafazadeh, R.; Hayeri, V.; Willis, A.C. Polyhedron, 2010, 29, 1810-1814. DOI: 10.1016/j.poly.2010.02.030.

38. Bytheway, I.; Wong, M.W. Chem. Phys. Lett. 1998, 282, 219-226. DOI: 10.1016/S00092614(97)01281-5

39. Socrates, G. Infrared and Raman characteristic group frequencies, John Wiley \& Sons, Chichester, 2004.

40. 40. Deacon, G.B.; Phillips, R.J. Coord.Chem.Rev. 2008, 33, 227-250.

41. Maslejova, A.; Boca, R.; Dlhhan, L; Papankova, B.; Svoboda, I.; Fuess, H. Chem.Phys.Lett. 2001, 347, 397-402.

42. Faniran, J.A; Patel, K.S., Baliar, J. Inorg. Nucl. Chem. 1974, 36, 1547-1551. DOI:10.1016/00221902(74)80621-4.

43. P.E. Aranha, M.P. dos Santos, S. Romera, E.R. Dockal, Polyhedron 26 (2007) 1373.

44. Rehman, S.U.; Sarwar, T.; Husain, M.A.; Ishqi, H.M.; Tabish, M. Arch. Biochem. Biophys. 2015, 576, 49-60. DOI: 10.1016/j.abb.2015.03.024

45. Sirajuddin, M.; Ali, S.; Badshah, A. J. Photochem. Photobiol. B Biol. 2013, 124, 1-19. DOI: 10.1016/j.jphotobiol.2013.03.013

46. Nakamoto, K.; Tsuboi, M.; Strahan, G.D. Drug-DNA Interactions, John Wiley \& Sons, Hoboken, New Jersey,2008.

47. Brissos, R.F.; Torrents, E.; dos Santos Mello, F.M.; Pires, W.C.; de Paula Silveira-Lacerda, E.; Metallomics 2014, 1853-1868.

48. Inclan, M.; Albelda, M. T.; Frias, J. C.; Blasco, S.; Verdejo, B.; Serena, C.; Canela-Salat, C.; Diaz, M. D.; Garcia-Espana, A.; Garcia-Espana, E., J. Am. Chem. Soc. 2012, 134, 9644-9656

49. Norden, B.; Tjerneld, F.; Palm, E.; Biophys. Chem.1978, 8,1-15. 